\title{
Comment
}

\section{MOVIE CENSORSHIP AND THE SUPREME COURT: WHAT NEXT?}

"Free speech for movies." Thus was heralded the decision of the United States Supreme Court in May, 1952, in Joseph Burstyn, Inc. v. Wilson ${ }^{2}$ that motion pictures were entitled to the protection of the First Amendment to the United States Constitution. Nearly twenty months later, in January, 1954, the Court reaffirmed this position in Superior Films v. Dept. of Education. ${ }^{3}$ The purpose of this comment is to determine how the states have responded to this ruling of the Court, and to speculate on the implications of the most recent decision of the Court as to the future of movie censorship.

\section{THE PATTERN OF CENSORSHIP}

Until 1952, it was settled law in America that movies were not entitled to any substantive constitutional protection from state censorship. A state or community could freely require that movies be submitted for official approval prior to any showing. The Supreme Court gave its blessing to this practice in Mutual Film Corp. v. Industrial Commission, ${ }^{4}$ which was consistently followed by the state and lower Federal courts. ${ }^{5}$ The rationale for denying to movies the protection of free speech was that movies were a business "pure and simple," and conducted solely to entertain and anuse, not to educate or inform. ${ }^{6}$

Free from constitutional impediments, the censor was little affected by any kind of judicially-imposed restraints. First, the lengthy process of appealing to the courts was often of no aid when the picture was of current value, particularly for newsreels. Further, the state courts were not anxious,

1 N.Y. Times, May 27, 1952.

2343 U.S. 495 (1952).

8346 U.S. 587 (1954).

4236 U.S. 230 (1915). The decision did not hold technically that movies were not within the protection of the United States Constitution, since it was not until 10 years later that the First Amendment free speech guaranties were made applicable to the states through the Four. teenth Amendment, Gitlow v. New York, 268 U.S. 652 (1925), but the case has had the same impact. RD-DR Corporation v. Smith, 183 F.2d 562 (5th Cir.), cert. denied, 340 U.S. 853 (1950).

5E.g., Buffalo Branch, Mutual Film Corp. v. Breitinger, 250 Pa. 225, 95 Atl. 433 (1915) (upholding the Pennsylvania law); Pathe Exchange v. Cobb, 202 App. Div. 450, 195 N.Y. Supp. 661 (3d Dep't 1922), af'd, 236 N.Y. 539, 142 N.E. 274 (1923) (New York law upheld even as to newsreels); Mutual Film Corporation v. Chicago, 224 Fed. 101 (7th Cir. 1915) (sustaning Chicago ordinance); RD-DR Corporation v. Smith, 183 F.2d 562 (5th Cir.) (sustaining Atlantic ordinance), cert. denied, 340 U.S. 853 (1950).

${ }^{6}$ Probably few Supreme Court decisions have received the sustained and devastating criticism poured on Mutual Film Corp. v. Industrial Commission. E.g., see CEAFEE, FrEE Speech IN THE United States 540-548 (1941); Ernst, The First Freedom 181-244 (1946); Kupferman and O'Brien, Motion Picture Censorship-The Menphis Blues, 36 CoRNelr L. Q. 273 (1951); Comment, 49 YaIe L.J. 87 (1939); Notes, 39 Col. L. REv. 1383 (1939), 60 YaIE L.J. 696 (1951). 
as a routine matter, to hinder the censors. The general rule was no reversal unless the administrative action was capricious or arbitrary. ${ }^{7}$ Thus, the censors were free to protect the public not only from salacious and scandalous films, but from those presenting unorthodox social and political ideas as well. ${ }^{8}$ Nor was there any effort along procedural lines to require from the censors reasons and detailed findings for their rulings rather than the mere parroting of statutory language. ${ }^{?}$

Within this legal framework, or lack of it, movies in America have been subjected to an intensive, diversified, and confusing pattern of censorship. ${ }^{10}$ The nature of this pattern may be illustrated by sketching the path of a "controversial" picture through the amazing labyrinth of authorities. "The Moon is Blue," an American picture released in 1953, is wellsuited for this purpose. ${ }^{11}$ While this study of the picture's difficulties does not purport to be exhaustive, it does indicate some of the troubles that beset the producer, distributor, and exhibitor of motion pictures.

"The Moon is Blue" was a light-hearted romantic comedy, adapted from the successful stage play of the same name. Its chief vice apparently was the blatant use of several words, not obscene, but not conventionally used in movies, for example, "virgin," "seduce," and "preguant."12

T E.g., Distinguished Films v. Stoddard, 271 App. Div. 715, 68 N.Y.S.2d 737 (3d Dep't 1947) (it is enough if "some reviewing bodies would think this film offended"); Hallmark Productions, Inc. v. Dept. of Education, 153 Ohio St. 595, 93 N.E.2d 13 (1950); In re Goldwryn Distributing Corporation, $265 \mathrm{~Pa} .335,108$ Atl. 816 (1919).

8 The emergence of racial "message" pictures from Hollywood in recent years caused some Southern cities considerable tribulation. No implications of social equality among the races could be tolerated. For example, "Curley" was banned in Memphis, see Umited Artists Corporation v. Board of Censors, 189 Tenn. 397, 225 S.W.2d 550 (1949), cert. denied, 339 U.S. 952 (1950), and "Lost Boundaries" was excluded from Atlanta, see RD-DR Corporation v. Smith, 183 F.2d 562 (5th Cir.), cert. denied, 340 U.S. 853 (1950). On the other hand, "The Birth of a Nation" was banned in Maryland because of its anti-Negro character. N.Y.Times, May 14, 1952 , p. 15, col.1. (The final resolution of subsequent judicial proceedings is not known to the writer. N.Y.Times, June 14, 1952, p.12, col.8).

Various communities have sometimes been protected from what has been thought to be "communistic propaganda." In Maryland a post-war Polish documentary film was banned on this basis, Time, Oct. 31, 1949, p. 76, col. 2, and a Russian picture was similarly excluded from Providence, Rhode Island, see Thayer Amusement Co. v. Moulton, 63 R.I. 182, 7 A.2d 682 (1939).

${ }^{9}$ See Note, 39 Cor. I. REv. 1383, 1400-1401 (1939) for a detailed discussion of the working of the New York law. In at least one case a New York judge has dissented from upholding a censorship decree because of inadequate findings of fact. See Matter of Foy Productions v. Graves, 253 App. Div. 475, 481, 3 N.Y.S.2d 573, 578 (3d Dep't), aff'd, 278 N.Y. 498, 15 N.E.2d 435 (1938). See Kadin, Administrative Censorship, 19 B. U.L. REv. 533, 555 (1939).

10 The literature on this subject is overwhelming. The law review material cited in note 6 , supra, is extremely valuable, particularly the work of the Yale Law Journal. For an earlier study, see Legis., 44 HARv. L. REv. 113 (1930). An exhaustive analysis of the operation of the Ohio censors is ably presented in Brychta, The Ohio Film Censorship Law, 13 Omro St. L.J. 350 (1952).

11 While the problems of "The Moon is Blue" occurred in 1953 following the Burstyn v. Wilson decision (May, 1952), the censoring practices throughout the country had not altered significantly. However, the Kansas City decision referred to in text at note 31, infra, was based on the Supreme Court decisions discussed subsequently in this comment.

12 According to The Nation, sex in "The Moon is Blue" was "strictly antiseptic." 177 The. Natron 18 (July 1953). 
The picture's first troubles came not from any official censors but from purely private groups. The picture was demied a seal of approval by the Breen Office. ${ }^{13}$ This is the arm of self-censorship of the motion picture industry itself, and the agency which operates the most intimate and detailed censorship of any. ${ }^{14}$ The producers, "independents," undismayed by this, went ahead and distributed the picture. ${ }^{15}$

Then came another rebuff by a private group of no little significance. The Legion of Decency, a Catholic orgamization, condemned the movie because "it seriously offends and tends to deny or ignore Christian and traditional standards of morality and decency."16 The antipathy of these groups deserves first mention simce the influence on movie-making of the Breen Office and the various private pressure groups, while not within the scope of this comment, is probably of much greater significance than that of the state and local censors. ${ }^{17}$

The movie was then distributed to the seven states with official state censor boards which preview every picture to be shown in their respective territories. ${ }^{18}$ While their number is small, the impact of the policies of any

13 Technically, the Production Code Administration of the Motion Picture Association of America, but known to the public periodically as the Hays Office, the Johnston Office, and the Breen Office. For a good discussion of its evolution and operation, see INGLIs, FreEdom or THE MovIES 97-172 (1947).

14 For example, representatives of the Breen Office view Broadway stage plays and determine their suitability for adaption to the screen, and often work with the movie company right on the lot during the making of the picture. The Code itself is a marvel of detail and prudery. For example, the words "cripes" and "lousy" and the sound "razzberry" cannot be used. See INGTIS, FreEdoM of THE MOVIEs 153, 154, 207 (1947). Recently a seal of approval was granted to "Cease Fire," a movie about the Korean war, only on the condition that it be decontaminated of three "liells" and one "damn." N.Y. Times, Nov. 13, 1953, p. 24, col. 5. Samuel Gold. wyn has called for the revision of the Code to bring it "reasonably up to date," a job that seems long overdue. N.Y.Times, Dec. 29, 1953, p. 19, col.1.

15 This was the first defiance of the Code since Howard Huglies released "The Outlaw" without a seal in 1943. N.Y. Times, June 19, 1953, p.34, col.3. The fact that this was by an "independent" producer is significant since the bulwark of the Code is in the "major" studios. However, the later defiance of the Office by R.K.O., now controlled by Hughes, in releasing "The French Line" without a seal has been taken more seriously. N.Y.Times, Dec. 30, 1953, p. 16, col.4. However, the other major studios have reaffirmed their faith and devotion to the Code. N.Y. Times, Jan. 7, 1954, p. 27, col. 1. This action was probably in remembrance of the "crackdown" by the Legion of Decency in 1934 which originally caused the enactment of the Code and effective self-censorship by Hollywood. See INGLIS, FrEEDOM OF THE MOVIES 120-125 (1947).

16 N.Y. Times, June 10, 1953, p. 34, col.3.

17 Pressure groups of all kinds operate effectively at all levels. Sometimes a producer is discouraged from making a picture at all, see NoBLE, Negro IN Firms 218 (1948) (N.A.A.C.P. dissuaded production of "Uncle Tom's Cabi"), or the picture is altered to avoid offending, see Life, Oct. 25, 1945, p. 58 (clerical background of Cardinal Richelicu deleted from "The Three Musketers"). Once an objectionable picture is produced, the exhibitor may be discour. aged from showing it, see text at note 38 , infra, or the theatre may be picketed, see N.Y. Times, Feb. 3, 1953, p. 21, col. 4 ("Limelight," a Chaplin picture, picketed by war veterans), or even sacred authority may be invoked to discourage patronage, see N.Y. Times, Jan. 1, 1954, p. 16, col. 8 (Cathohics in St. Louis forbidden from seeing "The French Lime" under penalty of "mortal sin" by Archbishop Ritter). See generally Note, 60 Y ArE I.J. 696, 713-719 (1951).

18 Kansas Gen. Stat. AnN. \$\$ 51-101 to 51-112, 74-2101 to 74-2209 (1949); Md. AnN. Code Gen. LAws art. 66A, \$\$1-26 (Flack 1951); N. Y. Ed. Law \$\$ 120-132; OHo Rev. Cgde ANN. $\$ \S 3305.01-3305.99$ (Baldwin 1953); PA. Stat. ANN. tit. 4, \$§ 41-58 (1950); VA. Code 
one state board may reach far beyond the borders of that state and into others where no censorship is desired. This is due both to the distributional organization of the motion picture industry, ${ }^{19}$ and the normal desire of a producer seeking maximum revenues not to be excluded from the censoring markets. ${ }^{20}$ New York, Pennsylvania, and Massachusetts promptly approved "The Moon is Blue." 21 In Kansas the board demanded sixty-five deletions. ${ }^{22}$ In Maryland it was flatly banned until the action was reversed in the courts as "arbitrary and capricious." 23 What happened in Ohio and Virginia is not known to the writer.

While the picture had survived the state boards with little difficulty, it now encountered the crazy-quilt of local censorship. It has been estimated that there are from fifty to eighty local censorship boards in the country. ${ }^{2 A}$ Not all of them regularly preview all pictures to be shown. Some are only spurred into action when some picture a group feels objectionable is shown in the locality. ${ }^{25}$ The techniques of the municipalities in determining whether a picture may be shown vary from requiring police approval, ${ }^{26}$ to submitting the pictures to a librarian ${ }^{27}$ to the fiat of a voluntary committee which combs the reviews of the movies. ${ }^{28}$ Sometimes a city will utilize its

$\$ \$ 2-98$ to 2-116 (1950). Massachusetts maintains control over movie content by its Lord's Day Law which requires a license for Sunday showings. Mass. ANN. Laws c. 136, \$\$ 2-4 (1950).

Florida has a unique law making it a crime to slow any film not passed by the National Board of Review or the New York censors. FLA. STAT. $\$ \$ 521.01-521.04$ (1951). The validity of this is subject to considerable doubt, see Comments, 49 Y ALE L.J. 87, 89, n.41 (1939); 6 UNIV. or FIA. L. Rev. 131, 134-135 (1953). Louisiana has a censorship law on its books, LA. Rev. STAT. tit. 4, §§ 301-307 (1950), but it las not been actively enforced since the death of Huey Long. Connecticut formerly liad a censorship law, but it was repealed, see Comment, 49 YaIE L.J. 87, 91, n. 31 (1939).

At least five of these states exempt newsreels. Kansas Gen. Stat. ANn. § 51-103 (1949); N.Y. Ed. LAw § 123(1); OتIO Rev. CODE ANN. \$ 3305.01 (Baldwin's Rev. Code Service 1953); Pa. Stat. Ann. tit. 4, § 43 (1950); VA. Code \$ 2-106 (1950) (in discretion of censor). Often pictures for educational, charitable, or religious purposes are exempted, PA. STAT. AnN. tit. 4, $\$ 57$ (1950), but sometimes this is in the discretion of the ceusorship board. N.Y. ED. LAw $\$ 123(3)$; VA. CODE \$ 2-108 (1950). Pictures of a strictly scientific cliaracter intended for use by learned professions are often exempted. N.Y. ED. Law \$ 123(2); VA. CODE \& 2-107 (1950).

19 For purposes of distribution the nation is divided into exchange centers, several of which distribute prints to more than one state. Thus, if deletions are required in one state, the print will go on to other states in the same "purified" condition. For example, West Virginia and Kentucky see films censored in Ohio. See Comment, 49 Yale L.J. 87, 91-92 (1939).

20 It is the practice of the Breen Office to advise producers on the treatment likely to be given specific films by the more important state boards. INGLIS, FreEdOM OF THE MOVIES 156 (1947).

21 N.Y. Times, June 10, 1953, p.34, col.3.

22 N.Y. Times, Jan. 28, 1953, p. 24, col. 2.

23 N.Y. Times, Dec. 9, 1953, p. 11, col. 2.

${ }^{24}$ See Kupferman and O'Brien, supra note 6 at 276. For a list of various boards see Motion Picture and Television Alaranac 896-900 (1953-54).

25 Memphis Digest v. 1, \$\$1131-1139 (1931); Waterloo, Iowa, see Comment, 60 YaIE L.J. 696, 697 (1951). For a vivid discussion of the Meniphis practice, see Velie, You Can't See That Movie, Colkers, May 6, 1950, pp. 12 and 66.

20 Chicago Municipal Code $\$ 155-1$ et seq. (1939).

27 Atlanta Code $\$ \S 55-305,58-107,58-108,66-504$ (1942).

28 In Palo Alto, California, a citizens' committee was authorized by ordinance to ban movies on the basis of reviews obtained from showings elsewhere. When this practice was attacked in the courts, the city council removed the coercive effect from the coinmittee's rulings. S.F. Chronicle, Marcli 23, 1954, p. 18, col.4. This leaves only one local censorship board (Pasadena) in the state of California. S.F. Chroniele, March 22, 1954, p. 20, col.1. 
licensing power to effectuate control over the contents of the pictures shown. ${ }^{29}$ Somehow "The Moon is Blue" wandered througl this maze without great difficulty. For example, its showing was permitted by the police in Chicago with attendance limited to adults. ${ }^{30}$ Kansas City, Missouri, banned the picture, but the order was reversed in the courts. ${ }^{31}$

Probably the most dramatic of the difficulties "The Moon is Blue" was to encounter was one not usually labeled "censorship." Nearly all states and localities have laws or ordinances prohibiting the showing of obscene motion pictures. ${ }^{32}$ However, since these ordinarily are operative only after the picture is shown they are usually regarded as "subsequent" rather than the more obnoxious "previous" restraints. ${ }^{33}$ As a practical matter, however, the theatre operator may be arrested, and the film seized, even without a showing, on the usually imcluded charge of possessing an obscene or imdecent picture. In Jersey City and Elizabeth, both in New Jersey, the police seized prints of "The Moon is Blue" and arrested the respective theatre managers, in Jersey City at least before there was any showing of the picture. ${ }^{34}$ An injunction was sought in Jersey City, but denied because the police action was not "arbitrary or capricious." However, in both cities the grand juries refused to return an indictment charging the picture with obscemity. ${ }^{36}$ In Jersey City, after a showing of the picture, the exhibitor was again arrested by the tenacious authorities under a revised ordinance. ${ }^{37}$

29 In Milwauke, if an exhibitor does not comply with the deletions or recommendations of a voluntary committee, the Mayor "at his discretion" may revoke the exhibitor's license to operate a theatre. Milwaukee Code of Ords., $\$ \$ 83.2,83.7$ (1941).

30 N.Y. Times, June 23, 1953, p. 26, col.2.

31 Variety, March 3, 1954, p. 4, col. 5.

32 These laws providing criminal punisbment for the showing or possession of certain motion pictures take a variety of forms. In some states, movies are subjected only to the general criminal obscenity statutes, relating to books and shows of all kinds. E.g., Cax. PEN. CodE $\$ 311$ (1953); OKza. Stat. tit. 21, \$1021 (1951). In others, movies of general kinds are specifically prohibited. E.g., N. C. GeN. STAT. \$14-193 (1953) ("obscene or immoral"); TEx. STAT, PEN. CODE art. 612 (1948) ("obscene, indecent, or immoral"). While still other states are more specific. Irr. REv. Stat. c. 38, $\$ 471$ (1953) (making it unlawful to exhibit moving pictures which, inter alia, "expose the citizens of any race, color, creed or religion to contempt, derision or obloquy"); MONT. REv. CODES ANN. \$ 94-3573 (1947) (unlawful to show "any scenes or pictures depicting burglaries, train robberies, or other acts which would constitute a felony"). See Legis., 44 Harv. L. Rev. 113 (1930).

All federal control over movie content is of this subsequent restraint type. The Tariff Act prohibits the importation of obscene pictures, or those urging treason, insurrection, or forcible resistance to the laws of the United States. 19 U.S.C. \$1305 (1946). Domestically, it is unlawful to transport in interstate commerce any "obscene, lewd, lascivious, or filthy" films. 18 U.S.C. $\$ 1462$ (1946). Prosecutions are rare under this latter law. See Note, 60 YaLE L.J. $696(1951)$.

33 For a discussion and critical evaluation of the concept of "previons restraint" see Note, 49 Cor. L. REv. 1001 (1949).

${ }^{34}$ N.Y. Times, Oct. 15, 1953, p. 35, col. 6 (Jersey City) ; N.Y. Times, Jan. 1, 1954, p. 16, col. 2 (Elizabeth).

35 N.Y. Times, Oct. 17, 1953, p. 10, col. 6.

${ }^{36}$ N.Y. Times, Dec. 9, 1953, p.11, col. 2 (Jersey City); Varicty, March 10, 1954, p.12, col. 4 (Elizabeth).

37 N.Y. Times, Jan. 7, 1954, p. 26, col. 7. The authorities in New Jersey seem to have found due process of law a substantial impediment to their protection of the public morals generally. In Newark, "Latuko," a film of life in an African tribe, was confiscated by the police and the 
It is worth noting that had there been any substance to the claim of obscenity here, Jersey City and Elizabeth could have been adequately protected by enforcement of this "subsequent restraint."

Finally, the most effective of all pressure was successful in Putnam, Connecticut, where the exhibitor quietly withdrew the picture under pressure fronl interested groups. ${ }^{38}$

While this comment is concerned solely with state action, it must be apparent to the reader that if all state and local official censorship were declared void the most inportant restraints on large-scale movie makers, the Breen Office and organized pressure groups, would still be effective. However, it would then be possible for a producer to defy these groups and strive for public approval without fear of the coercive power of the state.

\section{THE IMPACT OF BURSTYN V. WILSON}

\section{The decision}

Suddenly the Supreme Court intruded itself into this setting. In May, 1952, the Court in Joseph Burstyn, Inc. v. Wilson ${ }^{39}$ stated without dissent: "[W] conclude that expression by means of motion pictures is included within the free speech and free press guaranty of the First and Fourteenth Amendments." ${ }^{40}$ Mutual Film Corp. v. Industrial Commission ${ }^{41}$ was expressly overruled. ${ }^{42}$

Two years later, the Burstyn decision still substantially states the modern constitutional law of movie censorship since the two subsequent decisions have been without opinion. ${ }^{43}$

The Burstyn case arose when "The Miracle," an Italian picture which supposedly ridiculed the Virgin Birth, was banned by the New York censors because it was, under the New York statute, "sacrilegious." 44 The New York Court of Appeals, in affirming the decision, construed "sacrilegious" to mean that "no religion, as that word is understood by the ordinary, reasonable person, shall be treated with contempt, mockery, scorn and ridicule ..."45 The Supreme Court reversed the decision, holding that this

exhibitor arrested. The confiscation was restrained by the court, which observed, "Only a narrow or unhealthy mind could find any depravity in the film." N.Y. Times, May 20, 1952, p. 27, col. 1. The arbitrary suppression of "pocket books" bas also been thwarted, see Bantain Books, Inc., v. Melko, 25 N.J. Super. 292, 96 A.2d 47 (Ch. Div. 1953).

38 N.Y. Times, Aug. 4, 1953, p. 14, col.3. The picture was withdrawn in Elizabeth, New Jersey, prior to the arrest referred to in note 34, supra. N.Y. Times, Oct. 29, 1953, p. 34, col. 6 .

30343 U.S. 495 (1952). The case naturally received much attention from the law reviews. E.g., see Notes, 41 Ky. L.J 257 (1953), 31 N. C. L. REV. 103 (1952), 4 WESTERN RES. L. REV. 148 (1953); Recent Cases, 37 MTNN. L. Rev. 209 (1953), 26 TEMrP. L.Q 192 (1952). The only unfavorable scholarly reaction was in Recent Decision, 27 Sr. JoEn's L. REv. 131 (1952).

40343 U.S. 495,502 (1952).

41236 U.S. 230 (1915). See text at note 4, supra, for discussion.

42 Burstyn v. Wilson, 343 U.S. 495,502 (1952).

43 Gelling v. Texas, 343 U.S. 960 (1952) ; Superior Films v. Dept. of Education, 346 U.S. 587 (1954).

44 N.Y.ED. LAw $\S 122$. See text at note 88, infra, for the whole of the section.

45 Joseph Burstyn, Inc. v. Wilson, 303 N.Y. 242, 258, 101 N.E.2d 665, 672 (1951). 
standard was constitutionally inadequate. While it was vague, ${ }^{48}$ it had a more serious defect. "... [T]he state has no legitimate interest in protecting any or all religions from views distasteful to them which is sufficient to justify prior restraints upon the expression of those views." 47

The Court did not purport to state any fixed and precise rules as to the validity of censorship per se. Movies were definitely entitled to freedom of speech. And censorship, requiring that permission to commumicate ideas be obtained in advance froin state officials, as a "previous restraint," was $a^{\text {" } . . . ~ f o r m ~ o f ~ i n f r i n g e m e n t ~ u p o n ~ f r e e d o m ~ o f ~ e x p r e s s i o n ~ t o ~ b e ~ e s p e c i a l l y ~}$ condemned." 48 However, admittedly a previous restraint miglit be imposed in "exceptional" cases. ${ }^{49}$ Apparently the Court was thinking here of a prior restraint in terms of the prohibition against the showing of a particular film, and not in terms of the requirement that all films be submitted for approval before any showing. This is suggested by the remark that, "... it is not necessary for us to decide, for exainple, whether a state may censor motion pictures under a clearly drawn statute designed and applied to prevent the showing of obscene films." 50 So while censorship as such was not necessarily invalid, the Court imposed a "heavy burden" on the state to justify the actual banning of a film pursuant to a censorship system..$^{51}$ The constitutional question would then arise as to the grounds upon which the film was banned.

However, there is a broader aspect to the decision. Until 1952, only one interest had been considered by the courts in dealing with movie censorship. ${ }^{52}$ This was the interest of the state in protecting its citizens from real or fancied threats to their morality and well-being through the potent mechanism of the inotion picture. That inovies through their method of presentation do have a strong impact on the attitudes and behavior of viewers is scarcely to be denied.53 And the large proportion of children which make up the movie audience has been thought to be particularly subject to these influences. ${ }^{54}$ This has resulted in many Americans feeling that movies must

46 ". . [ [T] $]$ he censor is set adrift upon a boundless sea amid a myriad of conflicting currents of rehigious views, with no charts but those provided by the most vocal and powerful orthodoxies." Burstyn v. Wilson, 343 U.S. 495, 504-505 (1952). Justice Frankfurter based his concurring opinion entirely upon the vagueness of the New York statute as construed. $I d$. at 507-540.

47 Id. at 505 .

$48 \mathrm{Id}$. at 503 .

49 Id. at 503-504.

50 Id. at 505-506.

51 Id. at 504.

52 See text at notes 4-9, supra.

53 This is due to the general effectiveness of fictional media in strengthening value preferences. See Berelson, Communications and Public Opinion in Comarunications IN MOdERN SoCIETY 167-185 (Schramm ed. 1948); Fearing, Influence of the Movies on Attitudes and Behavior, 254 Annars 70-79 (1947). Further, the unique technological features of motion pictures are likely to cause a high degree of attention and retention. See Charters, Motion Pictures and Youth in Reader in Public Opinion and Comanunications 397 (Berelson \& Janowicz ed. 1950); Hovland, Experdanents on Mass Communications (1949). For a detailed discussion, see Note, 60 YaLE L.J. 696, 707-709 (1951).

54 See Lazarsfield and Kendall, The Commtnications Behavior of the Average American in Mass Comorunications 389, 396-397 (Schramm ed. 1949). 
be subject to complete, even arbitrary, control and regulation for the preservation of what are thought to be "good" morals. ${ }^{55}$ However, the other interest involved here has largely been ignored. This is the imterest, on the one hand, of movie producers in making honest, realistic pictures that convey controversial, challenging ideas, and the complementary interest of citizens to view these pictures, even at the risk of having a prejudice or two shaken in the process. ${ }^{56}$ While the Supreme Court did not purport to write a code of movie censorship in Burstyn v. Wilson, it did say that the right of Americans to communicate, and receive, ideas must be given some consideration in the operation of any regulatory control over motion pictures. The states and cities were given fair warning that the era of total state interest was over. The majority of the Court did not follow Justice Frankfurter and simply declare the New York law void for vagneness. Instead they declared that movies were entitled to free speech protection. And even though this might not mean the application of the identical rules that govern other media of communication, ${ }^{57}$ it meant some protection, yet to be defined specifically. ${ }^{58}$

\section{The response}

The state legislatures and cities of America reacted to Burstyn v. Wilson by doing nothing. ${ }^{59}$ Technically the Supreine Court had only held that the use of the standard "sacrilegious" was invalid. This is not one of the more prevalent and often invoked standards, ${ }^{60}$ and so the legislative attitude was to sit tight and let the courts make the first move.

The judges had no such pleasant alternative. They were now faced with accommodating this new concept of freedom of speech for movies with

55 The very existence of censorship laws relating only to movies and to no other media of communication attests to this. See note 98, infra, for a vigorous statement along religious lines. Some law enforcement officials apparently consider movie censorslip a "vital weapon" in fighting juvenile delinquency. N.Y. Times, Dec. 29, 1953, p. 20, col.3 (Nathaniel Goldstein, Attorney General of New York).

56 According to Variety, out of 175 newspapers editorializing on state and local censorship in early 1954, 98\% opposed it in principle. Variety, Feb. 24, 1954, p. 10, col. 1.

57 'Nor does it follow that motion pictures are necessarily subject to the precise rules governing any other particular method of expression. Each method tends to present its own peculiar problems." Burstyn v. Wilson, 343 U.S. 495, 503 (1952).

58 A week after Burstyn v. Wilson, the Supreme Court held void a Marshall, Texas, ordinance which authorized a local board to deny a license to exhibit a picture whenever the board was "of the opmion" that the picture was "of such a character as to be prejudicial to the best interests of the people of said city." Gelling v. Texas, 343 U.S. 960 (1952). On its face, this ordinance appears impossibly vague, without any necessity for the Court to decide the free speech issue. The decision was per curiam, the Court citing Burstyn v. Wilson and Winters v. New York, 333 U.S. 507 (1948), the latter being a leading case on the doctrine of void for vagueness. Justice Frankfurter filed a concurring opinion asserting that the ordinance was void for vagueness, citing his own opinion in Burstyn.

59 The only exception to this known to the writer is the amendinent in Ohio in 1953 exempting newsreels from the censorship law. OHIO REV. CoDE ANN. $\$ 3305.01$ (Baldwin's Rev. Code Service 1953). However, this was probably prompted nore by State v. Smith, 108 NE.2d 582 (Ohio Municipal Ct. 1952), than by Burstyn. See text at note 73 infra.

60 For example, Kansas, Ohio, and Virginia have no such standard. See statutes cited in note 18 supra. 
the immensely varied and many faceted structure of censorship, both state and local, that had been reared on the now discredited notion that movies could be treated like carnivals. Unfortunately the judicial response has not been bold or imaginative, but rather seems to have been directed toward a verbal rationalization of the status quo.

In New York, "La Ronde," a French motion picture, was banned on the ground that it was "immoral" and "would tend to corrupt morals," in the terms of the New York statute. This decision was affirmed by the Court of Appeals." The court felt compelled to limit the statutory phrase "immoral" to "sexual immorality," ${ }^{2}$ and, as such, this was a satisfactorily definite standard "kindred" to "obscene or indecent." "3 A movie of a sexually immoral nature was thought to present such a "clear and present danger" of substantive evil that previous restraint was justified notwithstanding Burstyn v. Wilson. ${ }^{64}$

Meanwhile, in Ohio, "M", an American picture dealing with an insane child killer, was banned "on account of being harmful." The Ohio statute authorizes the censor board to approve only such films as are "of a moral, educational, or anusing and harmless character." The Ohio Supreme Court, in affirming this ban, thought that this statute outlined the "limited field" left in which "decency and norals" might be protected by censorship and was sufficiently definite for constitutional validity. ${ }^{60}$

These two cases are the only ones dealing with movie censorship to have reached the highest court of any state since Burstyn $v$. Wilson. In both state decisions there were vigorous dissents, ${ }^{67}$ and both were subsequently reversed by the United States Supreme Court. ${ }^{88}$ Since their reversal they do not express any law but they do express an attitude. In both cases freedom of speech for movies was admitted. But it was a different kind of freedom of speech than that to which other media of communication are entitled. All movies to be shown in a state may be subjected to previews

61 Commercial Pictures Corp. v. Board of Regents, 305 N.Y. 336, 113 N.E.2d 502 (1953).

62 This was the opinion of Froessel, J., in the leading opinion, concurred in by Lewis, J. However, concurring separately, Desmond, J., could see no reason to so limit "immoral" and thought it extended to anything contra bones mores. Id. at 349, 113 N.E.2d at 508. Conway, J., agreed with both opinions, whatever that means. Id. at 355, 113 N.E.2d at 512. Dye and Fuld, JJ., dissented. In view of the subsequent Supreme Court reversal there is apparently no need to puzzle out just how this mixture leaves New York law.

63 Id. at 346,113 N.E.2d at 507 .

$64 I d$. at 340,113 N.E.2d at 503 .

65 OHTO Rev. CODE ANN. § 3305.01 (Baldwin 1953).

66 Films, Inc. v. Dept. of Edn., 159 Ohio St. 315, 112 N.E.2d 311 (1953). The Ohio court also relied on the Mutual Films case, 236 U.S. 230 (1915), which had upheld the Ohio statute. The Ohio court pointed out that while Burstyn had overruled the old ease on First Amendunent applicability to movies, it had not overruled it as to the validity of the Ohio statute. This was true of course since in Burstyn only the New York statute was at issue. However, the use of this argument is an excellent illustration of the receptivity of the Ohio court to the idea of free speech for movies.

67 Two judges in each case dissented. In the New York case Fuld, J., indicated he thought all censorship was void. Counmercial Pictures Corp. v. Board of Regents, 305 N.Y. 336, 366, 113 N.E.2d 502,.519 (1953).

68346 U.S. 587 (1954) (the cases were joined for decision). 
for state approval, a procedure that would be unthinkable for newspapers. ${ }^{69}$ The constitutional limitation relates only to the grounds upon which the subsequent showing may be prohibited. Conveniently enough, the particular state statutes with which these courts are confronted are found to describe the constitutionally permitted sphere of grounds for prohibition without serious question. Further, attention is directed solely to the statute; the courts do not earnestly probe into the procedures or practices of the boards. ${ }^{70}$

While this approach is permissible within the Burstyn holding, it scarcely is consistent with the Burstyn "attitude." $\mathrm{x}$ There is not in either the New York or Ohio decision any expression of the initial animosity with which judges should properly view the imposition of a previous restraint on the communication of ideas. These courts do not seein cognizant of the "preferred position" of free speech which the state must overcome. In short, it is hard to believe that the majority of New York and Ohio judges have accepted fully the doctrine that movies are free speech. ${ }^{72}$ Their emphasis is completely on the need for protection of the public morality without serious appreciation of the constitutional rights involved. Yet it is the balance of these conflicting interests that is the goal of the Burstyn approach.

By contrast, there has been some judicial expression more consistent with an attitude of filling in the bare bones of the Burstyn decision, but not a great deal.

In a municipal court in Ohio, the state censorship law was declared void, at least as applied to newsreels. ${ }^{73}$ The judge thought that censorship of newspapers was invalid, and no "controlling distinction can be made between newsreels and newspapers."74

There were several reversals by different courts of the rulings of censors, ${ }^{75}$ but the evidence is too slight to imdicate any trend of greater judicial

69 For an example of how well-accepted this doctrine is see the admission by counsel seeking to uphold censorship in the argument before the Supreme Court on the Superior Films case. 22 U.S.L. Week 3182 (1954).

70 An interesting sidelight on the Ohio banning of " $M$ " is that the original German version of the picture was approved by the Ohio censors in 1933. The state of Ohio stipulated before the Supreme Court that the two versions did not differ materially in plot, subject matter or characterization; yet one was banned and one approved. Brief for Superior Films, Inc. as Appellants, p. 30, Superior Films v. Department of Education, 346 U.S. 587 (1954).

71 If the Supreme Court may take cognizance of a "mood" of Congress, Universal Camera Corp. v. Labor Board, 340 U.S. 474,487 (1951), then its own decisions may certainly be characterized with an" "attitude."

T2 Compare the attitude of the Ohio court, only two months after its decision in the " $M$ " case, toward a city ordinance for licensing of charity solicitors in American Cancer Society, Inc. v. Dayton, 160 Ohio St. 114, 114 N.E.2d 219 (1953) (holding the ordinance void for indefiniteness of standards).

73 State v. Smith, 108 N.E.2d 582 (Ohio Muricipal Ct. 1952).

74 Id. at 587. In addition the statute was too vague, and in the substantial fees charged by the censorship board, which far exceed the costs, there was a demal of equal protection. The Ohio statute is reproduced in text at note 65 supra.

75 For example, in Maryland the banning of "The Moon is Blue" was reversed by the Baltimore City Court, N.Y.Times, Dec. 9, 1953, P.11, col. 2 ; and in New York, the Appellate Division reversed a ban on "Teen Age Menace," a picture touching on the narcotics problem, N.Y.Times, Nov. 20, 1953, p.19, col. 5 . 
intervention. A police ban in Chicago on "The Miracle" continued even after Burstyn based on a city ordinance "prohibiting the exposure of adherents of a religion to ridicule." The County Circuit Court ruled the ban illegal on the ground that the picture did not fit within its terms. ${ }^{76}$ The validity of the ordinance was not questioned, although it seems almost identical to the New York construction of "sacrilegious" held invalid in Burstyn v. Wilson.

While no significant judicial decisions have been found in Maryland, ${ }^{77}$ an interesting opinion was delivered by the State Attorney General. ${ }^{78} \mathrm{He}$ observed that the Maryland statute was never intended to meet the test of constitutionality required by the Supreme Court in the Burstyn case. He asserted that the Board's authority was now limited to determining whether films were obscene or indecent in the standard sense. However, it is not apparent that the Board was greatly impressed by this.

A novel and interesting approach was indicated by the New Jersey Supreme Court in a case involving the refusal of a municipal officer to issue a license for the operation of a theatre exhibtiting burlesque shows. ${ }^{70}$ This relates to motion pictures particularly because the municipal control over theatre operation is a common means of controlling the content of movies shown. Here the license was denied because the applicant allegedly had a background of producing lewd burlesque shows. The trial court ordered the director to issue the license, and the highest court in New Jersey affirmed because of insufficient evidence to sustain the denial. However, in arriving at this conclusion the court considered the Burstyn decision as bearing strongly on the matter. First, freedom of speech was now extended to the production of plays and shows as well as movies. Further, while the city could validly impose a previous restraint on "lewd and indecent" productions consistent with the First Amendment, it had to overcome the presumption that the production (as speech) was protected. In this case, the mere hearsay evidence, combined with the lack of a hearing, was insufficient to overcome the presumption. These procedural and evidentiary requirements might also be usefully applied to routine movie censorship in an effort to reconcile a previous restraint with the First Amendment.

\section{SUPERIOR FILMS V. DEPT. OF EDUCATION: WHAT DOES IT MEAN?}

Both the New York and Ohio decisions discussed above, involving "La Ronde" and " $M$ ", were heard by the Supreme Court together ${ }^{80}$ On January 18,1954, the Court handed down its decision, which shall be referred to henceforth as Superior Films v. Dept. of Education. ${ }^{81}$ The decision may

76 N.Y.Times, July 15, 1953, p. 20, col. 4.

77 In Floyd Lewis Attractions v. Traub, 22 U. S. L. Week 2290 (Baltimore City Ct. 1953), while a censorship order was sustained, the Judge strongly urged that the case be taken to the Maryland Court of Appeals for a final decision on the validity of the Maryland law.

78 N.Y. Times, June 13, 1952, p. 19, col. 1 .

79 Adams Theatre Co. v. Keenan, 12 N.J. 267, 96 A.2d 519 (1953).

80 See text at notes 61-66 supra.

81346 U.S. 587 (1954). 
easily be reproduced here: "PER CURIAM. The judgments are reversed. Joseph Burstyn, Inc. v. Wilson, 343 U.S. 495, 72 S.Ct. 777, 96 L.Ed. 1098." Justice Douglas filed a separate concurring opinion, with which Justice Black agreed, saying flatly that censorship of motion pictures was unconstitutional as a "previous restraint" on freedom of speech. "I2 "In this Nation every writer, actor, or producer, no matter what medium of expression he may use, should be freed from the censor." 83

The immediate result of the decision is that "La Ronde" may now be seen in New York, and " $\mathrm{M}$ " is free to cause mischief in Ohio. However, even though this is a per curiam decision, it cuts a little deeper.

Unless the Supreme Court has quietly adopted a doctrine of "fact review" of movies, ${ }^{84}$ the necessary conclusion seems to be that now states may not ban pictures on the ground that they are "immoral," "sexually immoral" or "harmful." Since counsel for Ohio argued that the latter phrase had been limited by the Ohio court to mean "inciting to crime," 85 this standard may also be invalid, although the opinion of the Ohio court is ambiguous as to whether the phrase was so limited. ${ }^{86}$ Without probing into the rationale of the Supreme Court, this is in itself a substantial achivement. The New York censors, for example, who operate under a typical state censorship law, ${ }^{87}$ were once free to ban any movie that was "... obscene, indecent, immoral, inhuman, sacrilegious, or . . of such a character that its exhibition would tend to corrupt morals or incite to crime." ${ }^{88}$ After Burstyn and Superior Films, they have been limited to banming only those that are "... obscene, indecent, ... (or) inhuman ..."

However, in regard to the future of censorship, it is necessary to speculate on the reasons for this latest decision. The reaction of the press seems to be that the Court is simply calling for more definiteness in the standards set up for the censor's guidance. ${ }^{89}$ Constitutionally, the standards are void for vagueness. This is a doctrime which is not concerned with the power of

$82 I d$. at 588 .

83 Id. at 589.

84 Justice Reed, in his concurring opinion in Burstyn v. Wilson, suggested that the Court must "... examine the facts ... in each case to determine whether the principles of the First Amendment have been honored," and whether the film is ". . of a character that the First Amendment permits a state to exclude from public view." 343 U.S. 495, 506-507 (1952). While this is a possible approach, it presupposes a constitutional doctrine of what a state may, and may not, censor that has yet to be enunciated. Certainly this was not the Burstyn approach which looked solely to the statutory standard and wherein the particular film was scarcely mentioned. It also seems that ad hoc review of this kind would mean practically the abdication of the Supreme Court in this area.

8522 U.S.L. Week 3182 (1954).

${ }^{80}$ The syllabus by the court simply repeats the statutory language. 159 Ohio St. 315, 112 N.E.2d 311 (1953).

87 Except for the very broad Ohio law, see text at note 65 , supra, the other state laws are nearly identical to the New York statute. See statutes cited note 18 supra.

SS N.Y. ED. LAW $\S 122$.

${ }^{89}$ See Mayer, A Movie Exhibitor Looks at Censorship, The Reporter, March 2, 1954, p.35 at 38; N.Y. Times, Jan. 19, 1954, p. 1, col. 6; S.F. Chronicle, "This World," Feb. 21, 1954, p.11, col.1; Variety, March 10, 1954, p.12, col.3. The only scholarly comment so far is a brief Recent Decision, 52 MICH. L. REv. 599 (1954). 
the legislature over the subject matter of the law, but rather with whether the law as expressed gives fair notice to the public and provides a guide to adjudication. ${ }^{90}$ Where licensing is the means of enforcement, definite standards are necessary for adequate judicial review. It is not unreasonable to interpret Superior Films in this manner since "immorality," "sexual immorality," and "harmful" seem singularly devoid of any precise meaning. The latter standard seems particularly subject to attack on this score.

However, whatever the merits of this approach, it is not that taken by the majority of the Court in its only opinion on movie censorship in Burstyn v. Wilson, cited as authority for the Superior Films decision. There the New York standard of "sacrilegious" fell because the state was not permitted in the face of the First Amendment to protect religions from "views distasteful to them" through the method of previous restraints on the publication of those views. ${ }^{91}$ In short, the state was without power to interdict this kind of speech. Only under this analysis was it necessary for the Court to determine whether movies were protected by the First Amendment, and whether censorship was a previous restraint. Were the asserted defect one of vagueness, it would be immaterial whether the statute regulated the communication of ideas or the sale of potatoes, except as a matter of degree. ${ }^{92}$

Within the First Anendment analysis, however, a statute may be too "broad" as distinguished from too "vague." While the prohibited conduct may be clearly characterized, the law may be invalid in that it indiscriminately interdicts protected and unprotected conduct. ${ }^{93}$ And the Court will not re-write the statute. In Burstyn, Justice Clark carefully spoke of the New York law as "broad and all-inclusive," rather than "vague." course, as a practical matter a statute is likely to suffer from both the defects of "broadness" (as related to the First Amendment) and "vagueness." However, the concepts should not be confused.

Probably the best evidence that the majority in Burstyn were concerned with power and not with vagueness is Justice Frankfurter's concurring opinion therein which was devoted entirely to an attack on the New York law because of its vagueness. ${ }^{95} \mathrm{He}$ recognized the distinction by refraining

90 Winters v. New York, 333 U.S. 507 (1948) is the classic case. For a discussion of the Supreme Court cases, see Note, 62 HARv. L. Rev. 77 (1948); a detailed discussion of the California cases is in Comment, 41 CArIF. L. REv. 523 (1953).

81 Burstyn v. Wilson, 343 U.S. 495, 505 (1952).

92 It is generally thought that the requirement of definiteness is of greater importance when the regulated conduct relates to the communication of ideas rather than more inundane affairs. See Frankfurter's opinion, Burstyn v. Wilson, 343 U.S. 495, 533 (1952); Comment, 41 CALIF. L. REv. 523, 532 (1953). This facet of the "vagueness" rule apparently saves attack: ers of censorship from the argument that since the laws only prohibit the showing of unlicensed pictures, the exhibitors are given ample warning of the impact of the law when a license is denied.

93 E.g., Lovell v. Grifiin, 303 U.S. 444 (1938).

94 Burstyn v. Wilson, 343 U.S. 495, 504 (1952).

95343 U.S. 495, 507-540 (1952). The association of movie censorship with the doctrine of void for vagueness is probably due to this opinion. However, it is interesting to note that prior to Justice Frankfurter's opinion a unovie censorship law had never been leld void for vagueness. See Note, 60 YaIE L.J. 696, 698 (1951). 
from ever mentioning directly that movies were protected as free speech; under his aproach this was not necessary.

The failure of the court to cite a case in the Superior Films decision is also significant. In Gelling v. Texas, ${ }^{86}$ which immediately followed Burstyn and was decided per curiam, both Burstyn and Winters v. New York $k^{97}$ were cited. The latter is probably the leading Supreme Court case on "void for vagueness." The failure of the court to cite Winters this time may not unreasonably be interpreted to indicate that the Court was not so impressed with vagueness as with freedom of speech.

This is not a matter of jurisprudential hair-splitting. If the standards are only too vague, then the states need only imaginative draftsmen. Of course, the question of power would still be open. But if these standards fall afoul of the First Amendinent, the censors are, to that extent, out of business.

If then the Court here has apphed the Burstyn rationale to the New York and Ohio statutes, which the citation of the case would indicate, a state is simply without the power to ban a picture because it is "immoral," "sexually immoral," harmfnl," or will "incite to crime." A state cannot stop the showing of motion pictures in order to insulate the prevailing notions about morality in general, sexual behavior, or peaceable conduct, from competition by other ideas. This may be a bitter pill for the zealous to swallow, ${ }^{98}$ but it seems to be the Court's conclusion. This is not to say that the showing of pictures offensive in this respect caimot be regulated in any way and possibly even prohibited completely under "exceptional" circumstances, ${ }^{99}$ but it does indicate that the routine banning of pictures on any of these grounds is completely fimshed. And, if this is the correct interpretation, it is a matter of indifference in what detail a state may seek to set out the formal grounds for following this same approach.

96343 U.S. 960 (1952).

97333 U.S. 507 (1948).

98 Consider the remark of Bishop McVinney of Providence, Rhode Island: "The moneymad dealers in lechery now have the solemn blessing of the courts of the land. The law may no longer be invoked to stem the floods of spiritual and moral hemlock purveyed by the theatre." Variety, Feb. 24, 1954, p. 10, col. 2. However, Catholics in America are by no means of one view toward the merits of official censorship. See Clancy, Freedom of the Screen, 59 The Commonweal 500 (Feb. 19, 1954).

09 The Supreme Court decisions so far have been concerned solely with the problem of the complete banning of pictures. Whether the presentation of particular pictures might be limited and regulated to certain places and times is still open. Precedents from other areas of free speech suggest that this is not an entirely objectionable "previous restraint" so long as the standards are clear and reasonably related to the necessities of the community. For example, sound trucks may be regulated so as to prevent undue clamor. Kovacs v. Cooper, 336 U.S. 77 (1949), and parades regulated so as not to interfere with traffic, Cox v. New Hainpshire, 312 U.S. 569 (1941).

The showing of a picture might even be completely stopped where, under the particular circumstances of the situation, a breach of the peace is likely to occur. See Feiner v. New York, 340 U.S. 315 (1951); Chaplinsky v. New Hampshire, 315 U.S. 568 (1942). Query whether it is not more consistent with free speech ideals to protect the offensive speech or movie in this situation. See Terminiello v. Chicago, 337 U.S. 1 (1949). 


\section{THE FUTURE STATUS OF CENSORSHIP}

As of this moinent then, censorship is not per se invalid. But the sphere in which the censor may operate is very limited. A picture may not be banned because it is "sacrilegious," 100 "prejudicial to the best interests of the people,"101 "harmful," "inciting to crime," "immoral" or "sexually immoral." 102 In New York, bills have been pending which purport to clarify in detail the meaning of "immoral," and "inciting to crime." 103 As indicated above, ${ }^{104}$ the writer is dubious of the proposition that the Court's objections to censorship lie in "vagueness," and inore detailed statutes only pose the question of lack of power more sharply. However, it would be very brash to be dogmatic over a conglomeration of per curiam decisions.

A few rules seem to be clear. In all probability the censorship of newsreels is per se invalid. ${ }^{\mathbf{1 0 5}}$ Further, freedom of speech protection now probably extends to stage plays and shows as well as movies. ${ }^{100}$ The old arguments for denying protection to movies which were rejected in Burstyn are identical to those asserted against protecting stage plays. ${ }^{107}$ No distinction should be inade either between plays that are "pure entertainment" and those which carry a message. The line is too difficult to draw. ${ }^{108}$

As to what happens next, the burden is again on the state legislatures, city councils, and courts to accommodate their laws to this state of affairs, no matter how distasteful it might seem. It is too early now, of course, to assess the reaction. Two local censor boards have fallen since the Superior Films decision: one felled by the courts, ${ }^{109}$ one by a city council. ${ }^{10}$ The establishment of more definite and detailed standards, now being attempted in New York, is one step in the direction of striking a compromise, although possibly futile. Another approach is possible along procedural lines through a presumption of invalidity of the censor's decision, requiring detailed findings and reasons for the decision, and giving due account to the lack of a hearing, if such is the case. Merely a healthy skepticism by judges toward

100 Burstyn v. Wilson, 343 U.S. 495 (1952).

101 Gelling v. Texas, 343 U.S. 960 (1952).

102 Superior Films v. Dept. of Education, 346 U.S. 587 (1954).

103 For a verbatim description of the proposed bills, which are quite lengthy, see Variety: Feb. 24, 1954, p. 10, col.4; March 10, 1954, p.12, col.1, 5. Motion picture exhihitors have opposed the bills. Variety, March 10, 1954, p.12, col. 5.

104 See text at notes 89-99 supra.

105 State v. Smith, 108 N.E.2d 582 (Ohio Municipal Court 1952). Only Maryland, Massachusetts, and Virginia now censor newsreels. Ohio abandoned the practice after Slate v. Smilh. See note 59 supra.

106 Adams Theatre Co. v. Keenan, 12 N.J. 267, 96 A.2d 519 (1953).

107 Stage plays, like movies, have long been subject to nearly arbitrary local control. See generally, ChafEe, Free SpeEce IN TBE UNITED States 529-536 (1941); Grand and Angoff, Massachusetts and Censorship, 10 B. U.L. REv. 36, 147 (1930).

108 "What is one man's amusement, teaches another's doctrine." Winters v. New York, 333 U.S. 507, 510 (1948).

${ }^{100}$ The Cole County Circuit Court held the Kansas City, Missouri, law unconstitutional. Variety, March 3, 1954, p. 4, col. 5 . 110 Palo Alto, California. S.F. Chromele, March 23, 1954, p. 18, col.4. 
the censor's judgment would be an improvement. ${ }^{111}$ Whether the ground of "obscenity" would be upheld as a basis for censorship is still open, as it was in Burstyn v. Wilson. ${ }^{112}$ There is much to indicate that this standard would be sustained. ${ }^{113}$ No state has yet experimented with the British practice of "classifying" movies, that is, allowing only adults to view certain pictures, and recommending that minors do not see others. Regardless of the merits of this type of control, ${ }^{114}$ it would have a much greater chance of being sustained by the Supreme Court than the complete banning of a picture on any grounds whatever. This system would also be more consistent with the pohicy, always asserted by censorship advocates, of protecting youth. ${ }^{115}$

Without some innovation by the states in an attempt to balance the interests involved here, it is not all unlikely that the Supreme Court might lose patience with the whole business. The censors from six states, at a meetmg in New York following the Superior Films case, asserted that the decision imdicated that the Court approves in substance some form of official "pre-regulation" of movies. ${ }^{116}$ This is not true technically, of course, and is even doubtful as a prediction. All of the three decisions of the Court, since deciding that movies are protected by the First Amendment, have reversed a censorship decree. ${ }^{117}$ All have declared some standard of censorship invalid. No decision of the highest court of any state sustaining censorship has stood unscathed since that time. In Burstyn, the one opinion of the Supreme Court, the validity of censorship per se was expressly left open, which does not necessarily imply approval. Nor should too much be

111 The dissenting judges in the New York Appellate Division decision on "La Ronde" argued that "the rule should be ... [that] the determination of any board or bureau should only be upheld where it is clear that any conclusion to the contrary would not be entertained by any reasonable mind." Commercial Pictures Corp. v. Regents of the University of New York, 280 App. Div. 260, 265, 114 N.Y.S.2d 561, 566 (3d Dep't 1952).

112 See text at note 50 supra.

113 Several Supreme Court cases have indicated by dictum that a previous restraint to stop obscenity would be sustained. E.g., Chaplinsky v. New Hampshire, 315 U.S. 568, 571-572 (1942); Lovell v. Griffin, 303 U.S. 444, 451 (1937); Near v. Minnesota, 283 U.S. 697, 716 (1931). Whether this would require the states to impose the federal standard of obscenity as applied to books, that is, whether the book (or picture in this case) "taken as a whole has a libidinous effect," established in Umited States v. One Book entitled "Ulysses," 72 F.2d 705, 707 (2d Cir. 1934), or whether the states might apply the traditional test, "whether the tendency of the matter charged as obscenity is to deprave and corrupt those whose minds are open to such immoral influences, and into whose hands a publication of this sort niay fall," Regina v. Hicklin, L.R. 3 Q.B. 360, 371 (1868), is not clear. This might have repercussions as to whether a state could cut particular scenes or words, or would be limited to banning the picture as a whole.

114 The British gave "The Moon is Blue" an " $\mathrm{X}$ " certificate (positively no children), but the producer of the picture praised the British attitude as "sensible and helpful." N.Y.Times, Dec. 20, 1953, \& II, p. 5, col. 4. However, the fact that the British do occasionally completely ban a picture has caused some controversy over whether the system should be adopted. See the exchange of letters, New Republic, March 22, 1954, p. 22, col. 1.

115 See note 55 supra.

110 N.Y. Times, Jan. 22, 1954, p. 32, col. 3. "Pré-regulation" is the censor's euphemism for censorship.

117 Burstyn v. Wilson, 343 U.S. 495 (1952); Gelling v. Texas, 343 U.S. 960 (1952); Superior Films v. Dept. of Education, 346 U.S. 587 (1954). 
based on the failure of the rest of the Court to join in the Douglas opinion in Superior Films. While they might not agree with Douglas now that all censorship is illegal, this does not necessarily mean they think it is legal. It may be that a majority has yet to make up its mind, that they are waiting to see how the states respond to the challenge of the Burstyn case and revise their practices and procedures.

After all, it would hardly be revolutionary for the Supreine Court to declare all censorship void. Movies are the only means of communications muzzled by censorship. Nothing can be done about books or newspapers prior to publication. ${ }^{118}$ The capacity for evil of movies, that is stressed so inuch in this connection, seems to be no more than that of television which may not be subjected to state or local censorship. ${ }^{118}$ To require close judicial review of the censorship process would impose a substantial burden on the courts, and might mean only the substitution of judicial for administrative prejudices. Despite the common belief, there seems no substantial reason why decency cannot be preserved in a coinmunity through the subsequent restraint of the penal laws, ${ }^{120}$ although it is true that it is more difficult by this method to impose orthodoxy in the guise of decency. ${ }^{121}$ Further, the self-censorship of the movie industry itself, and the impact of pressure groups on all phases of movie making would seem enough to keep the industry in line with generally accepted norals. In short, unless there are some far-reaching atteinpts at self-improvement, state and local censors may find themselves deleted.

Albert W. Harris, Jr.

118 Near v. Minnesota, 283 U.S. 697 (1931).

119 The Federal Government bas occupied the field of radio and television regulation to the exclusion of the states and local governments. Allen B. Dumont Laboratories v. Carroll, 184 F.2d 153 (3d Cir. 1950), cert. denied, 340 U.S. 929 (1951), noted, 39 CAIIF. L. REv. 421 (1951) (Pennsylvania statute requiring approval by state censor of any film shown over television held void). While the Federal Communications Commission is forbidden to censor the content of programs, 47 U.S.C. $\$ \S 151,301-329$ (1946), it probably does exert some control over program content. See Segal, Recent Trends in Censorship of Radio Broadcast Programs, 20 Rocky MT. L. REv. 366 (1948); Note, 36 VA. L. REv. 496 (1950). In the selection among applicants for the himited number of channels available, this is probably inevitable.

120 The range of even these laws, however, inust be substantially limited in accordance with the Burstyn and Superior Films decisions. Some of the state laws are very broad. See note 32 supra. It would be incongruous, although not funny, for the Court to say a state lacks the power to ban a picture because it is "sacrilegious" or "immoral," and yet allow a state to imprison the exhibitor and confiscate the film on this sanse ground. Particularly is this true if the Court's objections are to the "vagueness" of the censorship laws; if a licensing law falls because of "vagueness," a fortiori a criminal law, with the same standard, inust fall. On the other hand, the "prior-subsequent restraint" analysis should not be pushed so far that when the former is held void, the latter is assumed to be valid; this approach causes the goals of the First Amendment to became obscure. See Note, 49 Cor. L. Rev. 1001 (1949).

121 The traditional procedural protections of the criminal accused (grand jury, public trial by jury, proof of guilt beyond reasonable doubt) are sometimes insuperable obstacles to the zealously intolerant. See the New Jersey experience, text at notes 34-37 supra. 